\title{
IDENTIFIKASI KEBIJAKAN PEMBERDAYAAN NELAYAN TRADISIONAL DI KAWASAN PESISIR PANTAI POPOH KABUPATEN TULUNGAGUNG
}

\author{
Hari Suprajitno \\ FISIP, Universitas Hang Tuah Surabaya \\ Email : hsprajitno.88@gmail.com
}

\begin{abstract}
Traditional fishermen in Popoh coastal area of Tulungagung Regency cannot be separated from the problem of poverty. This study aims to identify and analyze the policies of traditional fishermen empowerment carried out by the Fishery Office of Tulungagung Regency. This research used qualitative and descriptive approach. Data collection methods utilized in this study include observation, interviews, and documentation. Afterwards, the data were analyzed based on the interactive model of Miles and Huberman. The results show that there are three important phases of empowerment, namely initiation, participatory, and emancipatory phases. However, these three phases have not exhibited an optimal result. In the initiation phase, the government of Tulungagung Regency, through the Fisheries Service, has realized capital and equipment assistance to improve fishermen's welfare. Nevertheless, facts in the field indicate that the requirements for receiving this assistance are convoluted and do not meet the needs. Furthermore, in the participatory phase, training has been conducted but it cannot be implemented by the fishermen due to lack of capital. Meanwhile, in the emancipatory phase, fishermen cannot empower themselves at all because of the low desire to progress and develop.
\end{abstract}

Keywords: Policy, Empowerment, Fishermen

\section{PENDAHULUAN}

Wilayah pesisir pantai merupakan bagian dari sumber daya alam dan menjadi kekayaan alam yang perlu dijaga kelestariannya. Dalam UndangUndang Nomor 27 tahun 2007 pantai merupakan wilayah daratan yang posisinya proposional dan berada minimal seratus meter dari titik pasang tertinggi ke arah darat.

Selain dijadikan sebagai objek wisata, pantai memberikan sumbangsih kebutuhan ekonomi bagi para nelayan. Mata pencaharian sebagai nelayan adalah profesi yang paling banyak digeluti bagi kalangan masyarakat pesisir. Profesi sebagai nelayan merupakan profesi yang penuh dengan tantangan. Selain sengatan matahari, kondisi ombak dan pasang surut air laut sangat mempengaruhi hasil tangkapan mereka. Disisi lain harga ikan juga memiliki pengaruh dominan bagi pendapatan sebagai nelayan. Apabila harga ikan rendah disandingi dengan produksi yang terbatas, maka akan berdampak rendah pula terhadap pendapatan nelayan. Profesi sebagai nelayan identik dengan pengelolaan perikanan dalam mencukupi kebutuhan pangan. Namun profesi yang banyak digeluti oleh masyarakat pesisir ini masih berada dalam ketimpangan kesejahteraan sosial salah satunya nelayan tradisional.

Nelayan tradisional adalah orang yang melakukan usaha atau berburu ikan dan masih konservatif dalam menggunakan alat-alat tangkap ikan seperti ; perahu dengan kapasitas maksimum dua orang, mesin tempel berkapasitas 5,5 PK maupun alat tangkap berupa jaring dan pancing (Goso \& Anwar, 2017). Penelitian sebelumnya yang dilakukan oleh Safitri menyebutkan bahwa nelayan tradisional masih terjebak dalam kemiskinan akibat adanya beberapa pola kegiatan yang menindih kegiatan nelayan tradisional (Safitri, 2021). Hal ini disebabkan oleh kurang terpenuhinya kebutuhan dasar nelayan pada aspek permodalan, kebijakan pemerintah yang kurang berpihak maupun hasil tangkapan dengan kualitas rendah (Teguh Aris Munandar; Dadan Darmawan, 2020). Disisi lain kemiskinan dapat juga terjadi karena nilai-nilai kebiasaan nelayan yang bersikap pasrah terhadap keadaan dan kurang memiliki etos kerja yang baik (Suryaningsi, 2017).

Secara geografis pantai popoh terletak di Desa Besole Kecamatan Besuki Kabupaten Tulungagung Provinsi Jawa Timur dikenal sebagai destinasi wisata bahari yang indah dan asri. Wisata ini banyak diminati karena panorama pantai dengan lautan biru bersanding dengan hamparan pasir yang eksotis mampu memikat daya tarik pengunjung. Disamping majunya sektor pariwisata, pantai popoh memberikan arti kehidupan nelayan yang masih berada di lingkup kemiskinan. Keseharian para nelayan tradisional bergantung pada kondisi laut dan hasil tangkapan ikan yang terkadang hasilnya tidak seberapa. Keseharian nelayan tradisional rentan tersaingi 
dengan keberadaan nelayan-nelayan modern yang jauh lebih maju dalam mengelola perikanan. Disamping itu, keterhimpitan ekonomi memaksa mereka harus terlibat pada sistem hutang piutang kepada orang yang memiliki modal atau biasa mereka sebut sebagai pengambak.

Sistem hutang piutang oleh nelayan di kawasan pesisir pantai popoh dilakukan karena kurang terpenuhinya kebutuhan sehari-hari sebagai nelayan sehingga memaksa mereka untuk mencari alternatif lain seperti terlibat dalam sistem tersebut. Bukan tanpa konsekuensi, di tempat Pelelangan Ikan (TPI) nelayan yang terlibat hutang piutang dihadapi oleh monopoli perdagangan. Monopoli perdagangan ini dilakukan oleh pengambak yang telah memiliki jasa dalam meminjamkan uang kepada nelayan. Akibatnya nelayan harus mengikuti sistem ijon. Sistem ijon disini adalah menggantikan uang pinjaman dengan ikan hasil tangkapan nelayan.

Kemiskinan pada nelayan di kawasan pesisir pantai popoh didominasi akibat rendahnya pendidikan, keterbatasan modal dan permainan harga jual ikan di tempat pelelangan. Kondisi ini memerlukan bantuan pemerintah sebagai pemegang kendali sekaligus pemangku kebijakan (stakeholder) dalam menyelesaikan sekaligus memberikan solusi atas permasalahan yang ada.

Untuk menyelesaikan permasalahan tersebut dibutuhkan sebuah pemberdayaan guna memperbaiki kondisi ke arah yang lebih baik. Pemberdayaan umumnya menyangkut keberpihakan kepada rakyat kecil dalam meningkatkan kesempatan, kekuatan dan kemampuan dalam bertindak (Vibriyanti, 2014). Melalui proses pemberdayaan, nelayan tradisional akan memiliki wawasan baru mengenai pengelolaan ikan yang berkualitas, memahami teknologi sebagai alat tangkap dan melaut sehingga hasil tangkapan ikan akan jauh lebih baik daripada sebelumnya, hingga menemukan usaha baru dalam melakukan pengelolaan ikan agar dapat memenuhi kebutuhan hidup yang lebih sejahtera tanpa terlibat dalam sistem ijon.

Menyangkut pemberdayaan nelayan tradisional, Pemerintah Kabupaten Tulungagung melalui Perda Nomor 12 Tahun 2010 tentang pengelolaan usaha perikanan dan kelautan di Kabupaten Tulungagung telah mengatur pengelolaan usaha perikanan, perizinan maupun pembinaan dalam melangsungkan pengelolaan ikan oleh nelayan. Berada dibawah naungan Dinas Perikanan Kabupaten Tulungagung pemberdayaan nelayan tradisional dilakukan dengan tiga cara yaitu bantuan modal, bantuan peralatan dan pelatihan.
Dalam implementasinya selama ini di lapangan proses pemberdayaan yang dilakukan oleh Dinas Perikanan Kabupaten Tulungagung belum sepenuhnya dirasakan oleh nelayan tradisional di kawasan pesisir pantai popoh. Tidak meratanya bantuan yang diberikan bahkan bantuan yang tidak sesuai dengan kebutuhan menyebabkan nelayan masih berada dalam posisi stagnan di garis kemiskinan. Selain itu minimnya bantuan tersebut membuat nelayan tradisional tetap menggunakan cara lama dalam menangkap ikan. Sehingga hal ini menyebabkan nelayan tradisional di pantai popoh kalah bersaing dengan keberadaan nelayan modern yang terfasilitasi akan teknologi lebih maju.

Penelitian ini bertujuan mengidentifikasi kebijakan proses pemberdayaan yang dilakukan oleh Dinas Perikanan Kabupaten Tulungagung berdasarkan tiga analisis konsep pemberdayaan yaitu ; fase inisiasi, partisipatoris dan emansipatoris. Dari beberapa identifikasi penelitian terdahulu ditemukan bahwa selama ini sebagian besar nelayan tradisional kurang diberdayakan. Penelitian ini menemukan beberapa kebijakan pada beberapa fase bersifat statis.

Sebagai Organisasi Perangkat Daerah (OPD) yang memiliki tugas pokok dan fungsi terhadap masalah perikanan. Pantai popoh merupakan destinasi wisata yang cukup familiar di Jawa Timur khusunya Kabupaten Tulungagung yang memliki potensi kekayaan laut cukup melimpah membuat penelitian ini menarik untuk dilakukan. Dukungan objek wisata yang memadai seharusnya memberikan potensi kehidupan yang lebih maju jika dibandingkan pada daerah yang tidak memiliki potensi wisata sama sekali. Namun dalam realitasnya sektor pariwisata yang memadai tidak menjamin potensi kehidupan masyarakat akan lebih baik seperti halnya yang terjadi pada kehidupan nelayan tradisional di kawasan pesisir pantai popoh.

\section{TINJAUAN PUSTAKA}

\section{Kebijakan Publik}

Secara umum kebijakan publik menyangkut segala keputusan pemerintah untuk menyelesaikan problematika yang dihadapi oleh sebuah Negara. David Easton (dalam Anggara, 2018) menyatakan bahwa "Public policy is the authoritative allocation of values fo the whole society" yang berarti terdapat pengalokasian nilai-nilai yang sah ataupun gagasan yang ditujukan kepada seluruh masyarakat.

Pada hakikatnya kebijakan publik merupakan instrumen untuk mencapai sebuah tujuan. Tujuan tersebut berkaitan dengan wujud kepublikan 
diantaranya ; pertama mengidealkan masyarakat berupa prinsip keadilan, persamaan dan keterbukaan. Kedua, pemecahan masalah yang dihadapi masyarakat seperti masalah kemiskinan, pengangguran, kriminalitas maupun pelayanan publik. Ketiga, memberikan peluang baru untuk kelangsungan hidup yang lebih baik seperti investasi dan inovasi pelayanan. Keempat, melindungi masyarakat dari praktik yang dapat merugikan masyarakat seperti membuat UndangUndang (Handoyo, 2012).

Peran strategis pemerintah sebagai public actor dalam pemahamannya memerlukan aktualisasi kebijakan yang berorientasi kepada rakyat, dibutuhkan konsistensi yang tegas sehingga mampu memberikan perlindungan dan kepentintingan rakyat secara menyeluruh (Alamsyah, 2016).

Menurut Jann \& Wegrich (dalam, Ramdhani \& Ramdhani, 2017) pelaksanaan kebijakan publik mencangkup beberapa unsur yang ditetapkan oleh pemerintah meliputi ;

1. Rincian program, dalam hal ini bagaimana sebuah lembaga atau organisasi menjalankan program yang telah ditafsirkan.

2. Alokasi sumberdaya, menyangkut anggaran yang didistribusikan, personil dan organisasi yang bertanggungjawab atas pelaksanaan program.

3. Keputusan, bagaimana keputusan akan dilakukan.

Pada hakikatnya proses kebijakan publik sebagai tindakan yang mengarah pada tujuan diperinci berdasarkan kategori-kategori tertentu meliputi ; policy demands (tuntutan kebijakan), policy decisions (keputusan kebijakan), policy statements (pernyataan kebijakan), policy outputs (keluaran kebijakan) dan policy outcomes (hasil akhir kebijakan) kategori ini menspesifikasi kebijakan publik dalam praktiknya (Wahab, 2017). Lebih lanjut rincian tersebut sebagai berikut ; pertama, tuntutan kebijakan menyangkut desakan kebijakan yang ditujukan kepada aktor-aktor kepentingan untuk mengambil sebuah tindakan tertentu. Kedua, keputusan berkaitan dengan keabsahan dalam bentuk legitimasi dalam pelaksanaan kebijakan publik. Ketiga, pernyataan kebijakan yang dimaksudkan sebagai pernyataan resmi termasuk ketetapan pemerintah. Keempat, keluaran kebijakan merupakan wujud kebijakan publik yang direalisasikan melalui keputusankeputusan sebelumnya. Sedangkan yang kelima hasil akhir kebijakan ialah akibat atau dampak yang benar-benar dirasakan oleh masyarakat.
Dengan demikian kebijakan publik mengacu pada setiap pemecahan masalah berupa keputusan yang dilakukan oleh stakeholders dan menyangkut tujuan yang berorientasi kepada masyarakat. Umumnya keluaran kebijakan publik melalui tahap implementasinya, dilaksanakan dengan berbagai program sebagai sarana dalam membentuk kegiatan yang berkaitan dengan penyelesaian masalah yang dituju.

\section{Konsep Pemberdayaan}

Pemberdayaan merupakan bentuk kepedulian terhadap orang yang tidak berdaya menjadi berdaya. Bentuk pemberdayaan dapat dilakukan oleh siapapun dengan tekat membangun kehidupan antar sesama menjadi lebih baik (Saeful, 2020). Pemberdayaan biasanya ditujukan pada kelompok rentan memiliki keterbatasan dalam menyambung kehidupan sehari-hari.

Pemberdayaan memiliki beberapa fungsi ; pertama memenuhi kebutuhan dasar sehingga terbebas dari kelaparan, kobodohan dan kesakitan. Kedua, menjangkau sumber-sumber produktif guna meningkatkan pendapatan untuk memperoleh barang dan jasa yang diperlukan. Ketiga, dapat berpartisipasi dalam proses pembangunan (Suharto, 2014). Disisi lain pemberdayaan membentuk kemandirian individu dalam menghadapi segala problematika yang dihadapi dan meminimalisir potensi yang kurang menguntungkan.

Menurut Pranarka dan Prijono (1996) proses pemberdayaan masyarakat terbagi dalam beberapa fase yakni ;

1. Fase inisiasi, artinya proses pemberdayaan yang berasal dari pemerintah dan ditujukan kepada masyarakat.

2. Fase partisipatoris, yaitu proses pemberdayaan yang berasal dari pemerintah bekerjasama dengan masyarakat dan diperuntukkan bagi masyarakat.

3. Fase emansipatoris, yang berarti proses pemberdayaan berasal dari masyarakat, dilakukan oleh masyarakat, diperuntukkan untuk masyarakat dan mendapatkan dukungan dari pemerintah.

Ketiga fase tersebut menggambarkan pelaksanaan proses pemberdayaan yang berbedabeda. Pada fase inisial masyarakat cenderung pasif, bergantung pada pemerintah dan menerima maupun melaksanakan apa yang telah direncanakan oleh pemerintah. Sementara pada fase partisipatoris proses pemberdayaan dilakukan 
dengan bekerjasama dengan masyarakat sekitar sehingga ada jalinan kerjasama yang kuat dalam memberdayakan kelompok rentan. Sedangkan pada fase emansipatoris masyarakat sepenuhnya memiliki peran dalam melakukan proses pemberdayaan dan pemerintah sebatas pendukung.

Secara konseptual proses pemberdayaan membutuhkan kolaborasi antar stakeholders. Melalui kolaborasi yang tepat, pemberdayaan dapat berjalan efektif dan efisien. Selain itu kolaborasi membentuk jalinan yang baik antar pihak-pihak yang terlibat di dalamnya baik pemerintah, swasta ataupun masyarakat itu sendiri.

Menurut Schuftan (1996) pemberdayaan masyarakat dapat dilakukan dalam empat pendekatan sebagai berikut ;

1. Pelayanan/Jasa (Service Delivery) adalah pembangunan masyarakat yang menunjuk pada tindakan yang berhubungan dengan kegagalan pembangunan.

2. Membangun Kapasitas (Capacity Building) artinya pembangunan masyarakat dengan meningkatkan pengetahuan, kesadaran dan keterampilan untuk menanggulangi penyebab kegagalan pembangunan.

3. Advokasi (Advocacy) merupakan penetapan proses dinamis dalam membangun konsensus dan mandat dari suatu tindakan.

4. Mobilisasi Sosial (Social Mobilization) adalah menempatkan orang-orang yang terlibat aktif dalam penilaian analisis aksi dari proses pembangunan yang menunjuk pada penyebab dasar kegagalan pembangunan sebagai usaha meningkatkan pemberdayaan.

Berdasarkan hal tersebut pemberdayaan memiliki berbagai cara yang dapat ditempuh untuk memutus nasib buruk yang terjadi pada masyarakat kurang mampu, serta menjadi langkah strategis dalam melawan kemiskinan dan keterbelakangan.

\section{METODE PENELITIAN}

Penelitian ini menggunakan metode kualitatif deskriptif. Adapun metode pengumpulan data dilakukan dengan observasi, wawancara dan dokumentasi. Situs penelitian berlokasi di Desa Besole Kecamatan Besuki Kabupaten Tulungagung Provinsi Jawa Timur. Observasi dilakukan secara langsung di kawasan pesisir pantai popoh dengan menemui beberapa informan penelitian yakni nelayan tradisional, masyarakat dan Dinas Perikanan setempat.
Pengumpulan sumber data primer dan data sekunder pada sesi wawancara dilakukan secara face to face dan memberikan kesempatan seluasluasnya kepada informan untuk menyampaikan informasi pemberdayaan nelayan tradisional di kawasan pesisir pantai popoh. Selain itu pengamatan dilakukan dengan merasakan, mendengar dan melihat secara langsung objek penelitian lapangan.

Lebih lanjut data yang telah terkumpul diolah dan dianalisis dengan model interaktif Miles and Huberman berdasarkan tiga langkah (Sugiono, 2014) diantaranya sebagai berikut ; pertama, peneliti melakukan reduksi data yaitu melakukan seleksi data berdasarkan temuan-temuan di lapangan sesuai dengan tema penelitian kebijakan pemberdayaan nelayan tradisional di kawasan pesisir pantai popoh. Kedua menyaji data, hal ini dilakukan guna mempermudah proses penarikan kesimpulan berupa penyusunan informasi yang telah terstruktur seperti implementasi kebijakan, proses pemberdayaan dan dampak bagi nelayan tradisional. Ketiga verifikasi, melakukan penarikan kesimpulan yang berkaitan atas jawaban dari rumusan masalah identifikasi kebijakan pemberdayaan nelayan tradisional yang dilakukan oleh Dinas Perikanan Kabupaten Tulungagung.

Selanjutkan penelitian diuji keabsahan datanya agar dapat menakar tingkat ketepatan penelitian. Pada penelitian ini peneliti menggunakan teknik triangulasi yang terdiri dari ; triangulasi sumber yaitu cara peneliti mengecek kebenaran sumber informasi lapangan yang dilandasi dengan sumber-sumber lain seperti dokumentasi resmi Dinas Perikanan Kabupaten Tulungagung, jurnal maupun buku. Sementara pada triangulasi teknik dikembangkan dengan membandingkan sumber data yang satu dengan yang lain baik pada proses wawancara, dokumentasi maupun observasi yang berkaitan dengan masalah pemberdayaan nelayan tradisional. Sedangkan pada teknik waktu keabsahan data dilakukan dengan membandingkan ketepatan data pada selang waktu yang berbeda (Sugiono, 2014).

\section{HASIL DAN PEMBAHASAN}

\section{Kemiskinan Nelayan Tradisional di Kawasan Pesisir Pantai Popoh}

Nelayan sebagai kelompok mayoritas masyarakat yang berdomisili disekitar kawasan pesisir, secara umum kehidupannya tidak terlepas dari hasil laut. Bergantung pada hasil kelautan yang tidak menjanjikan, belum menjamin para nelayan tradisional di kawasan pantai popoh hidup dalam 
kondisi kesejahteraan yang memadai. Kemiskinan masih dialami oleh nelayan lantaran rendahnya kualitas sumber daya manusia karena sebagian nelayan hanya tamatan sekolah dasar bahkan belum tamat sekolah dasar. Selain itu lemahnya fungsi dari keberadaan Kelompok Usaha Bersama (KUB), lemahnya ekonomi mikro dan kapasitas organisasi masyarakat.

Kemiskinan yang terjadi pada nelayan tradisional sangat disayangkan, mengingat Kabupaten Tulungagung mempunyai potensi sumber daya perikanan yang melimpah. Potensi perikanan di Kabupaten Tulungagung dikenal sebagai penghasil budidaya ikan air tawar yang dikelompokkan pada dua usaha yaitu budidaya ikan hias dan konsumsi. Ikan hias dikhususkan pada beberapa jenis ikan diantaranya ikan mas koki (kaliko, tosa, raskel, mutiara, lion head, mata kantong), mas lowo, tekim, spenser, rensil dan jenis ikan lainnya. Sedangkan ikan konsumsi berorientasi pada pasar dengan jenis yang mendominasi adalah ikan lele, gurame, tombro, nila hitam dan tawes.

Usaha perikanan tersebut telah dikembangkan sebagai produk unggulan Kabupaten Tulungagung dan dipasarkan di berbagai daerah seperti Jakarta, Bali, Bandung, Yogyakarta, Tegal, Semarang, Surabaya, Purwokerto, Sumatea dan Sulawesi bahkan telah menjalin hubungan dengan eksportir dari Jakarta dan Bali.

Kehidupan nelayan tradisional di kawasan pesisir pantai popoh masih bergantung pada peran tengkulak. Hal inilah yang menyebabkan mereka berada dalam kondisi kemiskinan. Bagi nelayan persoalan utama yang dihadapi jika musim panen tiba ialah bagaimana mereka harus menjual ikan secepat mungkin karena produk perikanan yang kurang tahan lama ditambah lagi tidak tersedianya fasilitas pengawetan sehingga untuk memperoleh uang sebelum ikan tersebut membusuk maka mereka harus rela menerima pembayaran yang kurang memuaskan dari para tengkulak.

Nelayan tradisional di kawasan pesisir pantai popoh kurang mampu dalam membeli peralatan canggih dalam penggunaan tangkap ikan. Mereka masih menggunakan alat pancing dari senar, jaring, perahu dan mesin tempel dengan kualitas rendah yang menyebabkan mereka hanya bisa melaut sebatas jarak 1-2 mil dari tempat tinggal mereka. Dengan peralatan tangkap yang demikian, mereka belum maksimal dalam memanfaatkan sumber daya laut yang tersedia. Sehingga hasil yang mereka dapatkan belum optimal. Meskipun letak tempat tinggal mereka memiliki potensi sumber daya laut besar.
Kebijakan pemerintah masih sangat dibutuhkan untuk merangsang agar kekuatan atau potensi yang telah dimiliki oleh nelayan tradisional bisa lebih optimal digunakan dalam upaya mereka meningkatkan pendapatan, karena dengan mereka dapat memanfaatkan seoptimal mungkin potensi yang dimiliki, maka ini berarti mereka telah mempunyai kekuatan atau telah berdaya dalam menentukan kehidupannya.

Mereka belum mampu mengatasi kekuatan besar yang berada di luar jangkauannya, masalah yang mereka temui dari pihak luar belum mampu diatasi sendiri, seperti masalah terbatasnya akses mereka untuk mendapatkan pinjaman modal.

Oleh karena itu, peran pemerintah daerah dituntut maksimal dalam memberdayakan masyarakat, dimana dalam setiap program yang akan dilaksanakan harus melibatkan masyarakat dan selalu mendengarkan aspirasi masyarakat dalam hal mengawasi jalannya proses pembangunan agar tujuan dari pemberdayaan masyarakat dapat tercapai. Masyarakat yang berdaya dengan ciri-ciri: demokratisasi, kesetaraan masyarakat dengan pemerintah, kebebasan berbicara, kebebasan berkreatifitas, hak untuk merencanakan, hak untuk mengelola aset lokal, hak untuk mengawasi jalannya roda pemerintahan, hak untuk menikmati jerih payah sebagai buah pembangunan adalah sekaligus tujuan yang akan dituju oleh gerakan pemberdayaan masyarakat.

\section{Proses Pemberdayaan Nelayan Tradisional Di Kawasan Pesisir Pantai Popoh}

Fase-fase proses pemberdayaan nelayan tradisional di kawasan pesisir pantai popoh dilalui dengan tiga tahap pemberdayaan sebagai berikut :

\section{Pemberdayaaan Fase Inisiasi}

Pemberdayaan pada fase inisiasi dilakukan oleh pemerintah ditujukan kepada masyarakat nelayan. Dalam hal ini nelayan hanya menerima dan melaksanakan apa yang telah direncanakan pemerintah. Pemberdayaan pada tahap ini dapat dilihat dari segi bantuan yang disalurkan pemerintah Kabupaten Tulungagung melalui Dinas Perikanan berupa bantuan modal dan bantuan peralatan.

Secara spesifik bantuan modal disalurkan oleh Dinas Perikanan Kabupaten Tulungagung dalam program paket Pengembangan Usaha Mina Pedesaan Pengelolaan dan Pemasaran Hasil Perikanan (PUPM-P2HP). Bantuan modal tersebut diharapkan dapat menjadikan usaha perikanan nelayan jauh lebih berkembang. Dalam hal ini nelayan diberikan fasilitas agar mampu mengolah ikan menjadi barang yang memiliki nilai kualitas 
tinggi daripada hanya dijual berupa hasil tangkapan ikan.

Olahan ikan tersebut diharapkan dapat menjadi usaha kreatif nelayan seperti membuat olahan ikan menjadi bebagai olahan krupuk, pepes, ikan asapan maupun olahan lain yang berbahan dasar ikan. Dengan demikian pemerintah berharap hal ini menjadi penunjang kebutuhan nelayan dapat terpenuhi dan terjadi peningkatan jumlah penghasilan melalui usaha kreatif sehingga nelayan tidak lagi hanya bergantung pada hasil tangkapan ikan dimana hasilnya bergantung pada kondisi laut.

Meskipun telah ada bantuan dana yang disalurkan oleh Dinas Perikanan Kabupaten Tulungagung hal ini bukan berarti bantuan tersebut mudah didapatkan secara cuma-cuma. Untuk mendapatkan bantuan tersebut dibutuhkan persyaratan administratif yang harus dipenuhi yakni pengajuan proposal. Bagi nelayan tradisional hal ini sangat memberatkan lantaran minimnya pengetahuan tentang pembuatan proposal pengajuan dana tersebut. Sumber daya manusia yang rendah menjadi faktor nelayan tidak ingin repot mengajukan bantuan. Mereka jauh lebih memilih berusaha mandiri meskipun secara terpaksa harus berurusan dengan masalah hutangpiutang.

Disisi lain pemerintah menyalurkan bantuan lain seperti bantuan peralatan. Peralatan yang diberikan kepada nelayan seperti jaring, mesin kapal, lampu sorot dan jenis barang hibah lainnya. Bantuan peralatan yang disalurkan oleh pemerintah sama halnya dengan kendala yang terjadi pada bantuan modal. Keluhan nelayan tradisional untuk mendapatkan bantuan tersebut adalah bantuan peralatan yang diterima bersifat kelompok. Sehingga untuk mendapatkan bantuan tersebut harus terdaftar dalam Kelompok Usaha Bersama (KUB). Bagi nelayan yang bergerak secara individu hal ini sangat diskriminatif. Bantuan tidak bersifat perorangan melainkan secara kelompok. Bagi nelayan tradisional hal ini menjadi salah satu aspek yang menyebabkan mereka masih berada dalam kondisi kemisikinan. Bantuan peralatan sebagai pendukung hasil tangkapan ikan dengan kualitas baik justru tidak berpihak pada nelayan karena penyaluran bantuan yang tidak merata.

Tabel 1

Jenis Bantuan yang Diterima KUB Nama KUB Jenis Barang

\begin{tabular}{ll}
\hline Sinar Laut & 10 piece Jaring \\
\hline Green Fish & Pancing Rawai \\
\hline Sinar Samodra & Pancing Rawai \\
\hline
\end{tabular}

\begin{tabular}{ll}
\hline Pokmaswas MPB & Perahu Ekowisata \\
\hline Pokmaswas & 10 Life Jacket, 10 \\
Masyarakat Peduli & Rompi Pengawasan, \\
Bencana (MPB) & 1 Kamera, 1 \\
& Teropong, 2 Lampu \\
& Sorot. \\
\hline Pokmaswas Putra & 10 life jacket, 10 \\
Laut Selatan & Rompi Pengawasan, \\
(PLS) & 1 Kamera, 1 \\
& Teropong, 2 Lampu \\
& Sorot.
\end{tabular}

Sumber : Dinas Perikanan Kabupaten Tulungagung 2019

Selain kendala yang dihadapi nelayan tradisional secara individu. Disisi lain nelayan yang menerima bantuan melalui Kelompok Usaha Bersama (KUB) masih mengeluhkan bantuan peralatan yang diterima. Mereka mengeluhkan bantuan peralatan yang diberikan tidak sesuai dengan kebutuhan nelayan sehingga seringkali nelayan menjual kembali bantuan yang disalurkan oleh pemerintah tersebut.

\section{Pemberdayaaan Fase Partisipatoris}

Fase partisipatoris adalah tahap pemberdayaan yang dilakukan oleh pemerintah dan juga melibatkan pihak lain seperti swasta maupun swadaya lainnya. Pemberdayaan nelayan tradisional di kawasan pesisir pantai popoh selain dilakukan oleh pemerintah juga bekerjasama dengan organisasi lain.

Pemberdayaan pada tahap partisipatoris terwujud dalam agenda kegiatan pelatihan yang dilaksanakan oleh Dinas Perikanan Kabupaten Tulungagung bersama dengan Dinas Perikanan dan Kelautan Provinsi Jawa Timur, Unit Pelaksana Teknis Pelabuhan Pantai Popoh maupun Universitas. Jenis pelatihan yang ditawarkan seperti pelatihan perbaikan permesinan dimana ini sangat penting guna menambah pengetahuan nelayan dalam merawat instrumen kapal. Jenis pelatihan lain yang ditawarkan ialah pelatihan cara penanganan ikan yang baik di atas kapal. Hal ini menyangkut tentang cara penangkapan ikan yang benar tanpa merusak ekosistem laut dan menghasilkan hasil tangkapan ikan dengan kualitas tinggi. Selain itu sosialisasi keselamatan pelayaran juga menjadi dasar pelatihan yang disampaikan pada nelayan. Fungsinya untuk kelangsungan nelayan dalam mencari ikan dengan mengutamakan keselamatan kerja. Pemberdayaan lainnya juga melibatkan istri nelayan atau kelompok nelayan wanita dalam pengadaan pelatihan usaha ekonomi kreatif. Melalui pemberdayaan tersebut mereka dilibatkan dalam

6 | Hari Suprajitno | Identifikasi Kebijakan Pemberdayaan.... 
pembuatan kerajinan yang berasal dari potensi laut agar mereka dapat berjualan cinderamata di kawasan pesisir pantai popoh sebagai objek wisata Kabupaten Tulungagung.

Sejauh ini pelaksanaan pelatihan yang diberikan tidak teratur dilaksanakan. Untuk meningkatkan kesejahteraan nelayan melalui pelaksanaan pelatihan tanpa disandingi dengan bantuan modal yang mencukupi kiranya hal ini tidak efektif. Secara teori nelayan mampu memahami materi yang disampaikan dalam agenda pelatihan namun beberapa tidak bisa mempraktekkannya karena keterhimpitan modal.

\section{Pemberdayaaan Fase Emansipatoris}

Pemberdayaan emansipatoris adalah puncak proses pemberdayaan yang sepenuhnya dilakukan oleh masyarakat. Kondisi nelayan di kawasan pesisir pantai popoh pada saat ini belum mencapai tahap emansipatoris. Dengan kondisi seperti yang terlihat saat ini boleh dikatakan mereka sangat tidak berdaya secara ekonomi, akses terhadap modal sangat kurang. Hal ini terlihat dari berbelitbelitnya persyaratan yang harus dipenuhi. Hasil tangkapan hanya mencukupi untuk memenuhi kebutuhan hidup sehari-hari

Hasil pendapatan lebih memungkinkan untuk ditabung guna mencukupi kebutuhan mendesak. Bersatu padu dalam memberdayakan profesi sebagai nelayan sangat sulit dilakukan. Dibutuhkan keyakinan, pengetahuan, kemampuan dan kerjasama sedangkan hal ini belum terdapat dalam jati diri para nelayan di kawasan pesisir pantai popoh.

Rendahnya keinginan untuk maju dan berdiri sendiri dalam meningkatkan kesejahteraan hidup berpengaruh terhadap taraf kehidupan yang lebih baik. Nelayan tradisional di kawasan pesisir pantai popoh cenderung menerima keadaan dan rasa keinginan untuk berubah sangat kecil. Mereka lebih mengharapkan bantuan-bantuan pemerintah selayaknya dapat direalisasikan dengan merata. Bagi mereka pemerintah adalah harapan satusatunya yang dapat mengubah nasib jauh kebih baik. Kebijakan pemerintah dalam meningkatkan kesejahteraan nelayan merupakan penolong terbaik karena bersifat legal. Akan tetapi harapan tersebut berbanding terbalik dengan kondisi yang diharapkan nelayan.

Dalam hal ini kegiatan pemberdayaan yang disalurkan berupa beberapa bantuan nyatanya tidak dapat mencukupi kebutuhan nelayan. Disamping itu kemajuan untuk memberdayakan antar anggota masyarakat nelayan tidak mampu dilakukan.

\section{KESIMPULAN}

Identifikasi kebijakan pemberdayaan nelayan tradisional di kawasan pesisir pantai popoh belum optimal. Kemiskinan nelayan tradisional terjadi akibat rendahnya sumber daya manusia nelayan dan ketergantungan penjualan ikan kepada pengambak. Hal ini dikarenakan nelayan memiliki keterkaitan hutang piutang guna memenuhi kebutuhan hidup. Disisi lain proses pemberdayaan nelayan pada tahap inisiasi disalurkan dalam bentuk bantuan modal dan peralatan. Akan tetapi persyaratan pengajuan bantuan dana dianggap menyulitkan nelayan dan juga bantuan peralatan dinilai tidak sesuai kebutuhan. Selain itu pada tahap pemberdayaan partisipatoris telah dilakukan pengadaan pelatihan bersama organisasi lain belum mampu menyelesaikan masalah kemandirian nelayan dalam mendirikan usaha. Sedangkan pada tahap emansipatoris belum terjadi pada nelayan tradisional karena keterhimpitan ekonomi.

Demikian kebijakan yang tertuang dalam Perda Kabupaten Tulungagung Nomor 12 tahun 2010 tentang pengelolaan usaha perikanan dan kelautan belum mendasari beberapa aspek pemberdayaan yang notabene dapat menjadi sumbangsih dalam melakukan pemberdayaan pada nelayan tradisional. Pentingnya beberapa fase pemberdayaan dalam penelitian ini menafsirkan bahwa pemberdayaan sangat perlu dilakukan secara seksama antara Dinas Perikanan Kabupaten Tulungagung, pemerintah, swasta maupun nelayan itu sendiri untuk memenuhi konsep kebijakan yang lebih baik dan tidak bersifat statis.

Adapun saran yang penulis berikan yaitu :

1. Penyaluran bantuan modal lebih baik melalui lembaga keuangan yang pengelolaannya diberikan kepada masyarakat nelayan sendiri. Untuk itu, pada tahap awal dibutuhkan pelatihan dan pendampingan dari pihak pemerintah atau swasta dengan harapan masyarakat nelayan dapat mengelola keuangannya sendiri dalam lembaga tersebut.

2. Dalam pemberian bantuan peralatan sebaiknya pemerintah melakukan koordinasi bersama lembaga masyarakat nelayan atau kelompok nelayan yang ada di kawasan pesisir pantai popoh agar penyaluran bantuan peralatan sesuai dengan kebutuhan nelayan.

3. Melakukan monitoring secara rutin agar proses pemberdayaan nelayan menciptakan hasil kinerja yang baik disandingi dengan evaluasi kerja guna memperbaiki kondisi-kondisi sebelumnya. 


\section{REFERENSI}

Alamsyah, Kamal. 2016. Kebijakan Publik Konsep Dan Aplikasi, Media Citra Mandiri Press. Bandung.

Anggara Sahya. 2016. Pengantar Kebijakan Publik. Pustaka Setia.Bandung

Handoyo, E. 2012. Kebijakan Publik.Widya Karya. Semarang

Prijono, O,S \& Pranarka A.MW. 1996. Pemberdayaan : Konsep, Kebijakan dan Implementasi, CSIS. Jakarta

Suharto, E. 2005. Membangun Masyarakat Memberdayakan Rakyat : Kajian Strategis Pembangunan Kesejahteraan Sosial dan Pekerjaan Sosial. PT Refika Aditama. Jakarta.

Sugiono. 2014. Memahami Penelitian Kualitatif. Alpha Betha. Bandung

\section{Jurnal}

Goso, G., \& Anwar, S. M. 2017. Kemiskinan Nelayan Tradisional Serta Dampaknya Terhadap Perkembangan Kumuh. Jurnal Manajemen STIE Muhammadiyah Palopo, 3(1), 25-37.

Ramdhani, A., \& Ramdhani, M. A. 2017. Konsep Umum Pelaksanaan Kebijakan Publik. Jurnal Publik, 1-12.

Saeful, A \& Ramdhayanti. 2020. Konsep Pemberdayaan Masyarakat Dalam Islam. Jurnal Syar'ie 3, 1-17.

Safitri, F. 2021. Pemetaan Pola Kegiatan Ekonomi untuk Menentukan Model Pemberdayaan Ekonomi Nelayan Tradisional. Jurnal Pemberdayaan Masyarakat Papua (JPMP) 2(1), 1-9.

Scuftan, Claudio. 1996. The Community Development Dilemma : When Are Service Delivery, Capacity Building, Advocacy and Social Mobilisation Really Empowering? Community Development Journal. 31 (3).

Suryaningsi, T. 2017. Kemiskinan Masyarakat Nelayan di Desa Aeng Batu-Batu Kabupaten Takalar Sulawesi Selatan. Jurnal Handep 1(1) : 49-62.

8 | Hari Suprajitno | Identifikasi Kebijakan Pemberdayaan....
Teguh Aris Munandar; Dadan Darmawan. 2020. Implementasi Program Pemberdayaan Masyrakat Miskin pada Komunitas Nelayan Tradisional untuk Kesejahteraan Sosial Ekonomi di Lontar Kabupaten Serang. Jurnal Eksistensi Pendidikan Luar Sekolah, 5(2), 126-133.

Vibriyanti, D. 2014. Kondisi sosial ekonomi nelayan tangkap Kota Tegal Jawa Tengah. Jurnal Kependudukan Indonesia, 9(1), 4558.

Wahab. SA. 2017. Analisis Kebijakan dari Formulasi ke Penyusunan Model-Model Implementasi Kebijakan Publik. Bumi Aksara. Jakarta.

\section{Regulasi}

Peraturan Daerah Kabupaten Tulungagung Nomor 12 Tahun 2010 tentang Pengelolaan Usaha Perikanan dan Kelautan di Kabupaten Tulungagung

Undang-Undang Nomor 27 Tahun 2007 tentang Pengelolaan Wilayah Pesisir dan Pulau-Pulau Kecil 